\title{
Progressive primary pulmonary hypertension in a patient born at high altitude
}

\author{
D O'NEILL, R MORTON, J A KENNEDY
}

From the Cardiac Department, Western Infirmary, Glasgow; and Department of Pathology, Monkslands District General Hospital, Airdrie

SUMMARY A girl, born at high altitude, subsequently developed pulmonary hypertension which did not improve on return to sea-level and proved fatal at the age of 19 years.

The clinical and necropsy features were those of primary pulmonary hypertension, including a plexiform arteriopathy. There is a possibility of hypoxia in early life triggering progressive pulmonary vascular changes.

Although the pathogenesis of primary pulmonary hypertension remains obscure, it has long been established that exposure to the hypoxic stimulus of high altitude produces an increase in pulmonary arterial pressure in man and this increase may well be completely reversible. ${ }^{12}$ The characteristic vascular changes of primary pulmonary hypertension are rarely seen in the indigenous high altitude dwellers of the Andes, and there appears to be considerable variation in the susceptibility of the individual to develop pulmonary hypertension at altitude. ${ }^{3}{ }^{4}$ Several cases of pulmonary hypertension have been described in young children whose parents had recently settled at altitude in an area near Leadville and Climax in Colorado, and it was found that they improved on moving to a lower altitude and did not exhibit the usual progressive course of primary pulmonary hypertension. ${ }^{5}$

In this paper, we describe the clinical presentation and necropsy findings of progressive pulmonary hypertension in a girl who was exposed to high altitude in the Peruvian Andes for the first 15 months of life.

\section{Case report}

\section{HISTORY}

The patient, a 16-year-old girl, presented in 1974 with a history of tiredness and progressive exertional dyspnoea of three years' duration. Her history during early life was of particular interest.

She had been born of British parents at an altitude of 13000 feet in the Peruvian Andes. She had had a normal full-term delivery but at the age of 6 months she was failing to gain weight at a normal rate. At the age of 1 year, it was noted that her appetite and rate of weight gain improved while on holiday at sea-level. She returned to altitude and at the age of 14 months had an episode of acute respiratory distress. She returned to sea-level the following month and her general well-being improved almost immediately. She came to Scotland with her parents at the age of 2 years. Her overall growth and development were slow during childhood, but she caught up with her peers at puberty. At no time did she take oestrogen-containing preparations or slimming drugs.

\section{CLINICAL FINDINGS}

She was of normal stature and there was no central cyanosis. A giant a wave in the jugular venous pulse was present and there was an obvious right ventricular heave. Auscultation disclosed an accentuated pulmonary second sound with a pulmonary ejection click and a grade 4/6 pulmonary early diastolic murmur.

\section{INVESTIGATIONS}

The electrocardiogram showed sinus rhythm with gross right ventricular hypertrophy and right axis deviation. The chest $x$-ray film showed prominence of the main pulmonary artery. Right heart catheterisation was carried out and the pulmonary artery pressure was found to be $125 / 55 \mathrm{mmHg}$ (mean $90 \mathrm{mmHg}$ ) at rest. The right ventricular pressure was $125 / 0 \mathrm{mmHg}$ and the mean pulmonary wedge pressure $5 \mathrm{mmHg}$. No shunt was detected on oximetry. 
A provisional diagnosis of primary pulmonary hypertension was made and she was started on longterm Warfarin to prevent pulmonary arterial thrombosis. Her symptoms, however, slowly deteriorated, and within two years she was breathless on minimal exertion. Right heart catheterisation was repeated in 1977 and the findings were similar to those of 1974, the right ventricular systolic pressure being $150 \mathrm{mmHg}$. The diagnosis remained unchanged. Later in 1977, despite the addition of digoxin and propranolol, she died suddenly, aged 19 years, three years after presentation.

\section{NECROPSY FINDINGS}

\section{Gross appearances}

The heart weighed $400 \mathrm{~g}$ and showed severe hypertrophy of the right ventricle which measured approximately $35 \mathrm{~mm}$ in thickness $1 \mathrm{~cm}$ below the pulmonary valve. The tricuspid valve ring was dilated and the pulmonary valve appeared regurgitant. Both coronary arteries were normal in distribution and were patent throughout their length. The main pulmonary arterial trunk was thickwalled, severely dilated, and moderately atheromatous. There was no evidence of a septal defect and the ductus arteriosus was closed. The liver weighed $1200 \mathrm{~g}$ and had the typical "nutmeg" appearance of long-standing venous congestion. Nothing of significance was noted in the other organs. The cause of death was acute right ventricular failure secondary to pulmonary hypertension.

\section{Microscopical examination}

The most striking findings were florid hypertensive changes involving the pulmonary vasculature. Many of the muscular pulmonary arteries (100 to $1000 \mu \mathrm{m}$ in external diameter) showed prominent hypertrophy with crenation of the internal elastic lamina and several of them were occluded by intimal fibroelastic tissue ${ }^{6}$ (Fig. 1). In addition, plexiform and occasional angiomatoid lesions were present (Fig. 2). The elastic pulmonary arteries $(1000 \mu \mathrm{m}$ in diameter) were atheromatous. Of particular note was the similarity of the elastic fibre pattern of the pulmonary trunk to that of the aorta. An ischaemic infarct was present in the upper lobe of the right lung. The carotid bodies showed no hyperplasia of the major cellular components.

\section{Discussion}

It is probable that the disease known as primary pulmonary hypertension will prove to have more than one cause. A familial occurrence has been well established and impaired fibrinolytic mechanisms have been documented in one family with the disease, suggesting that recurrent miliary emboli

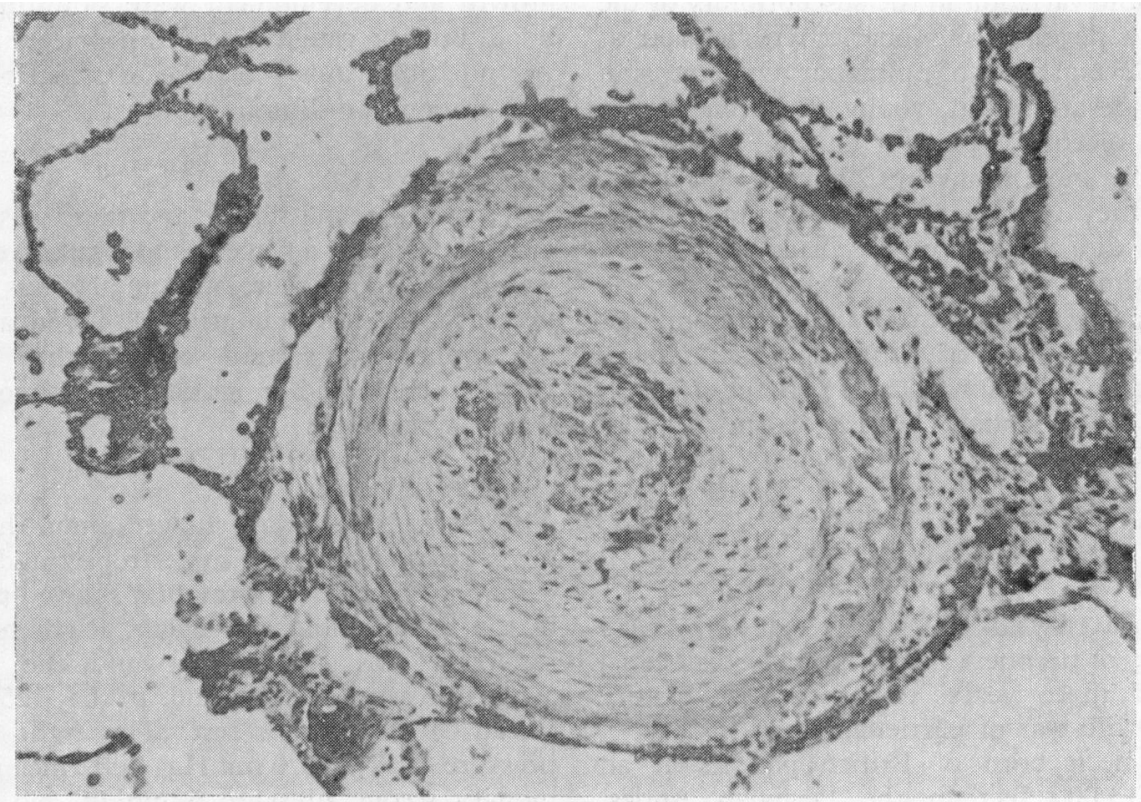

Fig. 1 Small muscular pulmonary artery exhibiting severe fibroelastic proliferation of the intima. 


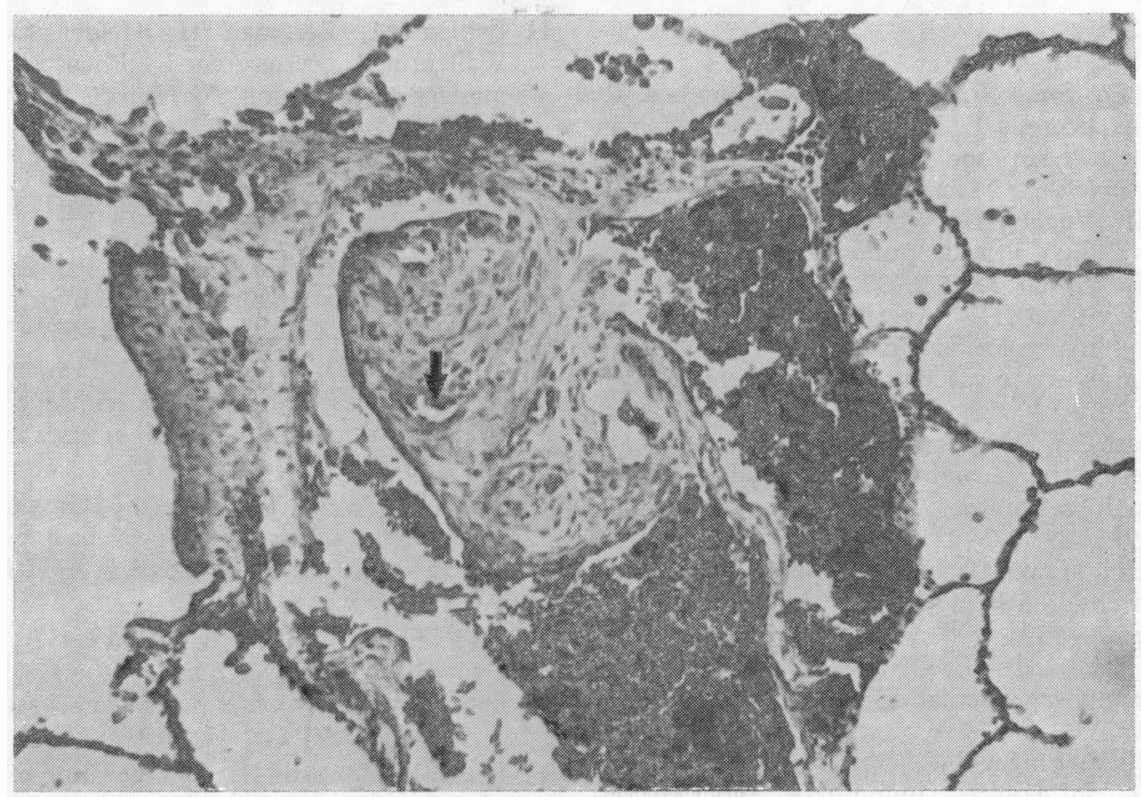

Fig. 2 Plexiform lesion characterised by proliferation of endothelial cells and fibrous tissue opening into a thin walled dilatation of the vessel. The lumen of the vessel is filled with fibrous tissue among which there is a proliferation of endothelial cells forming small vascular channels (arrowed).

may play a role. ${ }^{7}$ There is an apparent association between primary pulmonary hypertension and appetite suppressants, particularly aminorex fumarate, ${ }^{8}$ though all attempts to induce pulmonary hypertension in animals with this drug have failed. ${ }^{110}$ Biguanide (phenformin) treatment has also been implicated. ${ }^{11}$ Pulmonary hypertension is, of course, present in the normal fetus and involution of pulmonary arterial smooth muscle occurs after birth, provided that no abnormal stimulus produces pulmonary vasoconstriction. ${ }^{12} 13$ This abnormal stimulus is, however, provided by the hypoxia of altitude, and in such conditions there is persistence of fetal vasoconstriction and pulmonary vascular structure. $^{14}$ The pulmonary pressor effect of hypoxia appears to be direct and not mediated by humoral agents such as histamine ${ }^{15}$ or prostaglandin. ${ }^{16}$ Pulmonary hypertension of altitude is thought to be reversible ${ }^{2}$ and is usually well tolerated. ${ }^{1}$

In our patient the pulmonary arterial elastic fibres were thick, and concentrically arranged, and showed little branching, as in the aorta. Such a finding suggests that pulmonary hypertension had persisted from birth. ${ }^{17}$ In addition, there was florid plexiform arteriopathy, as seen in primary pulmonary hypertension. Such changes are also associated with intracardiac shunts, persistent ductus arteriosus, and hepatic cirrhosis, all of which were excluded in this case.

Although the vascular lesions of most patients with primary pulmonary hypertension are consistent with a vasoconstrictive pathogenesis, ${ }^{18}$ the disease appears to be rare among the Quechua people who have lived in the Andes for countless generations. Khoury and Hawes ${ }^{5}$ in 1963 described 11 cases of primary pulmonary hypertension in children of recent settlers in an area near Leadville and Climax, Colorado, at an altitude above 10000 feet. Two of the children died, but the remaining nine recovered when they were moved to lower altitude. Interestingly, the plexiform arteriopathy particularly associated with primary pulmonary hypertension was not described in these cases.

The present report records the occurrence of primary pulmonary hypertension in a young girl who was born at an altitude of 13000 feet, and it is suggested that exposure to this hypoxic environment at birth may have been responsible for the development of pulmonary vascular changes which progressed to the florid plexiform vascular changes usually associated with primary or idiopathic pulmonary hypertension.

We thank Professor Donald Heath for his help and advice. 


\section{References}

1 Peñaloza D, Sime F, Banchero N, Gamboa R, Cruz J, Marticorena E. Pulmonary hypertension in healthy men born and living at high altitudes. Am f Cardiol 1963; 11: 150-7.

2 Grover RF, Vogel JHK, Voigt GC, Blount SG Jr. Reversal of high altitude pulmonary hypertension. Am $\mathcal{F}$ Cardiol 1966, 18: 928-32.

3 Grover RF, Vogel JHK, Averill KH, Blount SG Jr. Pulmonary hypertension: individual and species variability relative to vascular reactivity. Am Heart $\mathcal{F}$ $1963 ; 66: 1-3$.

4 Wagenvoort CA, Sagenvoort N. Hypoxic pulmonary vascular lesions in man at high altitude and in patients with chronic respiratory disease. Pathol Microbiol (Basel) 1973; 39: 276-82.

5 Khoury GH, Hawes CR. Primary pulmonary hypertension in children living at high altitude. $\mathcal{F}$ Pediatr 1963; 62: 177-85.

6 Heath D, Edwards JE. The pathology of hypertensive pulmonary vascular disease. Circulation 1958; 18: 533-47.

7 Inglesby TV, Singer JW, Gordon DS. Abnormal fibrinolysis in familial pulmonary hypertension. Am $\mathcal{F}$ Med 1973; 55: 5-14.

8 Hatano S, Strasser T. (eds.) Primary pulmonary hypertension. Geneva: World Health Organization 1975.

9 Heath D. Dietary pulmonary hypertension (abstract). Br Heart f 1971; 33: 616.

10 Byrne-Quinn E, Grover RF. Aminorex (Menocil) and amphetamine: acute and chronic effects on pulmonary and systemic haemodynamics in the calf. Thorax 1972; 27: 127-31.
11 Fahlen M, Bergman H, Helder G, Ryden L, Wallentin I, Zettergren L. Phenformin and pulmonary hypertension. Br Heart f 1973; 35: 824-28.

12 Pool PE, Vogel JHK, Blount SG Jr. Congenital unilateral absence of a pulmonary artery: the importance of flow in pulmonary hypertension. Am $\mathcal{F}$ Cardiol 1962; 10: 706-32.

13 Vogel JHK, Averill KH, Pool PE, Blount SG Jr. Experimental pulmonary arterial hypertension in the newborn calf. Circ Res 1963; 13: 557-71.

14 Goodale F Jr, Thomas WA. Primary pulmonary arterial disease; observations with special reference to medial thickening of small arteries and arterioles. Arch Pathol 1954; 58: 568-75.

15 Tucker A, Weir EK, Reeves JT, Grover RF. Failure of histamine antagonists to prevent hypoxic pulmonary vasoconstriction in dogs. F Appl Physiol 1976; 40: 496-500.

16 Weir EK, McMurty IF, Tucker A, Reeves JT, Grover RF. Prostaglandin synthetase inhibitors do not decrease hypoxic pulmonary vasoconstriction. f Appl Physiol 1976; 41: 714-18.

17 Heath D, Edwards JE. Configuration of elastic tissue of pulmonary trunk in idiopathic pulmonary hypertension. Circulation 1960; 21 : 59-62.

18 Wagenvoort CA, Wagenvoort N. Primary pulmonary hypertension. Circulation 1970; 42: 1163-84.

Requests for reprints to Dr D O'Neill, Cardiac Department, Western Infirmary, Glasgow G11 $6 \mathrm{NT}$. 